\title{
Climate Change and Global Security in the 21st Century: A Geo-Political Assessment
}

\author{
Okhakhu, Poly Alens, PhD \\ Department of Geography and Environmental Management, Ambrose Alli University, Ekpoma, Nigeria \\ Tashok, Haruna Yusuf \\ Department of Architecture, Ambrose Alli University, Ekpoma, Nigeria
}

\begin{abstract}
This study examines climate change and global security in the current 21 st Century from the geo-political perspectives. Applying the specialist realist approach based on authentic first-hand environmental data and relevant literature, the study observes that climate change is caused by both natural processes and reckless human activities which defied standard environmental norms in the global climate system. Across the world, climate change has devastated the natural environments, settlements, human economic activities, and the built-up social facilities. These events led to food insecurity, joblessness, loss of wealth, political instability, migration overseas, emergence of diverse crimes, reinforced terrorism, and deadly civil-military wars which currently disrupt the viable global orders of stability, security, and peaceful human co-existence. Based on its findings, the study suggests viable measures to restore and sustain global security in climate change mitigation, prevention, and eradication, sound environmental maintenance, adequate supplies of food, jobs, and vital social benefits to the people, surface vegetal resurgence, crises resolution, and improved experts' services in agro-industrial, housing, transport, construction, recreation, evacuation, and military sectors. The realization of these global security measures requires the robust cooperation of sovereign authorities and international agencies.
\end{abstract}

Keywords: Climate Change, Global Security, Causes, Impacts, Assessment, Prevention.

DOI: $10.7176 / \mathrm{DCS} / 9-2-04$

\section{Introduction and Research Problem}

Across the different climatic regions of the world, the concept of climate change attracts a plethora of meanings from different scientists' assessments. In the current study, the realist specialist approach to its definitions is used. This approach, as Joseph (2012) argues, states that there are three levels into which any phenomenon, particularly in modern Climatology, can be structured. First, the underlying processes which cause things to happen; second, the events that they produce depending on the circumstances; and finally, the empirical observations of those events made by the experts. This approach accepts that in complex open environmental systems, the interacting mechanisms may not always produce an event. Events occur only when the mechanisms interact at the right place at the right time (Lane, 2001; Brown, 2004; Joseph, 2012).

It is on this premise we define climate change as the reckless pollution of the global habitat spurred by the utilization of fossil energy resources in diverse human activities which span mining, quarrying, agroindustrialization, construction of infrastructures, transportation and commerce where excess heat is given off and spread across the planet thereby altering the normal global climate cycle. As Ayoade (2004) puts it, climate change means the actual modification in the general circulation of the atmosphere on which climate ultimately depends. It implies the physical increase in the mean temperatures of the Planet Earth owing to reckless domestic, agro-industrial and military activities. In this regard, the polluting greenhouse gases such as methane, carbondioxide, nitrous oxide, aerosols, chlorofluorocarbons, perfluorocarbons and sulphur hexafluoride are released into the earth's atmosphere where they act as persistent visible barriers to the out-going infrared radiation to the outer space (Okhakhu, 2015; 2019). These holistic occurrences contribute to tremendous alterations in the natural climate processes, its patterns produced on the beneath environments, and means of interaction with the other significant global spheres, thus resulting to excess warming of the global climate system.

The adverse impacts of climate change are physically experienced on the global environment in the occurrences of torrential rains which cause flash floods or lack of precipitation which leads to drought, high solar radiation owing to some partly depleted ozone layers of the atmosphere, high mean temperatures, prevalence of harsh winds and extreme cold, massive presence or absence of clouds in the troposphere, and abundant humidity or lack of it which results to meteorological drought. Other impacts are the prevalence of devastative hurricanes, blizzards, whirlwinds and sandstorms, or absence of refreshing breezes which leads to poor ventilation and excess heat wave across the world, extreme floods and inundation of rural and urban settlements, preponderance of degraded soils for fruitful modern agriculture in the marginal locations of the world, thawing of permafrost and ice folds that causes marked depletion of the world's reserved fresh waters, seasonal invasion of pests and diseases of agro-sectors which leads to huge reduction of diverse agro-produce for both human and industrial uses, submersion of some coastal cities by ocean-sea surges inlands, and destruction of significant built-up rural- 
urban infrastructures by rainstorms, hailstorms, flash floods and extreme hurricanes (John, 2012; Mc Clatchey, 2012; Okhakhu, 2015; 2019).

In Iceland, Greenland, Denmark, Finland, Norway, Sweden, and Russia, vast snow fields and solid ice folds which have formed vital sources of the world's permanent fresh water reservoirs have begun gradual thawing owing to risen temperatures, eventually breaking down into the nearby ocean-sea waters. These events increase the ocean-sea water levels in the coastal settlements which result to marked water surges inlands that submerge pertinent coastal infrastructures and displace large groups of urban residents.

In Afghanistan, Iraq, Syria, Palestine and Yemen in the Middle East, persistent drought, extensive desertification, prevalence of hot winds and increased air temperatures have reduced sustained private and public agro-outputs. The inadequacy of food and cash crops, vital vegetal and livestock resources for human consumption and associated uses, increased joblessness of the youths coupled with despotic governance have, to some extent, fueled the current civil protests, youths unrests and deadly wars in these parts of the world. These similar events resulted to the Arab Uprisings in Tunisia, Libya, and Egypt in the Mediterranean Region of the World. Closely related are the current challenges of extreme poverty, collapsed economies, infrastructural decay and oppressive regimes which have spurred the current migrations of nationals from the South American countries of Honduras, Guatemala, El Salvador and Venezuela to Mexico in forceful tendency to settle down in the USA for sustainable jobs and improved standards of living.

In Africa, the impacts of climate change are complex to analyze. Destructive drought, enervating sandstorms, desertification, rainstorms, ravaging floods, pests and diseases, and risen temperatures have adversely reduced the availability of food-cash crops and livestock, raw materials for industrial production, income generation, employment, housing and market provisions, and community development. More so, the lucid inadequacy of the basic human necessities for sustenance has spurred the persistent search for diverse natural resources across the international borders of these tropical countries. These vast challenges, coupled with poor governance, decrepit socio-economic policies, uneven distribution of essential resources, decayed urban infrastructures, increasing youth joblessness, persistent ethnic cleansing, the Fulani attacks of innocent farmers and destruction of significant farm produce, terrorists attacks in major cities, and the incessant decimations of opponents for political consolidations have resulted to reckless shifts in powers in Africa. The holistic effects of these occurrences have manifested in depressive socio-economic situations, relentless criticisms, mass protests, unstable politics, rebellions, civil crises, and protracted deadly civil wars within the African Continent.

To escape these serious challenges for security, safety, and sustenance of lives, these Africans and other nationals within their midst have embraced the strategy of foreign migration across the harsh deserts, terrorist zones, drought landscapes, and vast oceans into the Middle East, Europe, Asia, North America and Australia as the ultimate panacea. However, these foreign migrations are faced with intractable hazards of human starvation, terrorist attacks, abduction of women for sex slaves and men for slave labour and ritual rites to create wealth, and ocean carnages and deaths. It is important to observe that most of these migrant youths in the foreign world lack adequate formal education to offer them gainful jobs. More so, some of these migrants are unable to operate decently within the ambit of the existing foreign laws. Attempts to survive in their missions in the foreign countries force them into illicit syndicates and lawless activities which include stealing, fraud, ritual magic, prostitution, drugs trafficking, burglary, vandalism, and armed robbery.

In the Middle East, America, Asia, and Europe, some of these jobless migrants have formed violent terrorist cells and dangerous syndicates which are elusive to identify, track down, and annihilate. These cells, in collaboration with the nationals, are currently prominent for intermittent bombings and shootings in populated workplaces, sport districts, markets, train stations, military camps, security checkpoints, airports, major night clubs, movie recreations, and the university campuses. These environmental, socio-economic and human challenges have transformed the current stable orders of security, peaceful co-existence and sustainable comfort of the world into risky chaos and unprecedented suffering of her peoples. It is against these challenges this current study examines Climate Change and Global Security in the 21 st Century from the Geo-political Perspectives using the realist specialist approach. As its objectives, this study assesses the impacts of climate change on global economic activities and social characteristics which adversely affect the world's stable order and security in the current 21 st Century.

\section{Research Methods and Materials}

This current study utilized authentic climatic, geomorphic, and foreign relations literature available in the public university libraries in Nigeria. The Collins' contemporary Atlas (2010) and precise satellite pictures of the countries greatly affected by extreme climatic forces such as heavy rains, flash floods, hurricanes, blizzards, sandstorms and wild forest fires displayed by the $\mathrm{BBC}, \mathrm{CNN}$, and Al Jazeera Televisions provided relevant research inputs for the study. These inputs formed parts of Tables 1, 2, \& 3 of the study. Having examined the physical and human environments impacted by these climatic forces in the humid tropical Nigeria, direct discussions were held randomly with some rural and urban residents to further ascertain the levels of these 
impacts on the current economic activities and social characteristics on the environment. It was on this premise the observed challenges were analyzed. Personal reflections and scientific assessments were carried out and these were prudently generalized for global applications in the current study. Above all, the realist specialist approach was adopted at the start of the research while the cause-effect analysis was used in the later part of the study.

\section{The Concepts of National Security and Global Security}

The concept of global security derives from the pertinent notion of national security. It exists because most sovereign states of the world have shown seemingly lack of adequate capacities to confront the challenges which arise from the occurrences of natural disasters, reckless human activities on the environment, and other inadequacies in the significant areas of agro-industrial production, environmental protection, health provision, rural-urban development, political measures against violent repressions of citizens, human rights abuses, crimes, and importation of terrorism into some countries. These malevolent impacts demand the unflinching cooperation, robust interconnection, and interdependence of the global community to mitigate, prevent, and resolve permanently with a purpose to establishing a safe, secure and productive world for the people and their diverse activities (Beres, 1979; Makinda, 1998; Mc Sweeney, 2003; Okhakhu, 2019).

It is based on this background that we refer to National Security as the protection, preservation, and sustenance of the holistic norms, beliefs, ethics, principles, institutions, infrastructures, resources, and the people of a sovereign country from all types of military hostilities, civil unrests and external aggressions. The concept cuts across the viability and ability of a sovereign state to provide all the basic human necessities for their existence and sustenance, defense of the people, including their protection against natural disasters, military hostilities, civil threats and attacks, insurrections by illicit syndicates and the terrorists. On the other hand, Global Security implies the authentic combination of efficacious measures adopted by countries and international organizations such as the United Nations, European Union, World Bank, African Union, Red Cross, and associated agencies to ensure their mutual protection, safety, survival, comfort, and sustainable development.

The global climate system is currently undergoing tremendous transformations particularly in the area of climate change which has imposed diverse challenges on both the natural environments and human built-up habitats. Consequently, huge security issues have arisen, beginning from the grass root through the national to the global levels which require salient assessment and termination in the current study. These security issues are itemized sequentially in the next sections.

The need to create secure, stable and sustainable environments immune from earthquakes, volcanic eruptions, ocean-sea surges inlands in the coastal settlements, overflows of continental rivers across their natural geomorphic banks, flooding on the slopes and fertile plains, and extreme run-off on the undulating surfaces. Others include the improvisation of effective environmental measures to mitigate, prevent, and resolve persistent environmental degradations, natural dangers and disasters, resources depletion, and widespread environmental pollution in the crude oil producing districts and refining regions of the world.

There should be effective planning and implementation of suitable agricultural production measures to eradicate global starvation and resolve the challenges created by unabated famine and diseases in the marine, forest, and continental regions, and drought-desert prone areas of the world.

There should be adequate provisions for safe, secure, and responsive human health alternatives against ravaging diseases, unsafe food for consumption, and impacts of malnutrition. The implementation of viable community measures against inter-ethnic, religious, economic, political, and related identity tensions in the different states of the world is urgently necessary.

There should be existence of personal legal provisions against physical violence with specific regard to the weaker female sex, child abuse, rape, domestic violence, crime, and import of terrorism.

Finally, suitable counter political measures must be taken to confront political detention of critics, suppress repression of political opponents, and prevent human rights abuses within and beyond the foreign frontiers of countries.

As it is in the global system today, the full capacity of one sovereign state to resolve the security challenges itemized in the preceding parts or with regard to provisions of food, health, jobs and housing is practically lacking. Most countries cannot achieve these measures without enlisting the mutual cooperation, unflinching support and pragmatic participation of the developed countries of the world and global financial institutions and agencies. Currently, there exists a common concern in the aspect of climate change-induced internal conflicts within some states over uneven distribution of vital national resources which results to full-blown wars thus triggering the problems of refugees that transcend the normal internal frontiers to resolve. There are other environmental disasters such as heat-induced tsunami, earthquakes, floods, and emergence of deadly diseases which also require sustained international cooperation, participation, and consolidated efforts to resolve pragmatically.

It is clear that climate change has denuded the natural environment, weathered its infrastructures, destroyed 
some important coastal settlements, displaced many urban residents, spurred heat waves across densely populated settlements, stimulated ravaging typhoons in the mid-latitude locations and destructive hurricanes in the temperate regions, and chaotically depleted vital resources in many sovereign states of the world. These events have exerted a renewed search by these powerful countries for vital national resources like crude oil, solid minerals, ocean-sea provisions, forest materials, fresh drinking waters and fertile soils beyond their foreign borders for sustained planning and rehabilitation. To achieve success in the acquisition of these natural resources, protect the producing sites from the vandals, illicit syndicates and terrorists, and sustain their national pride in these strategic locations require the use of modern technology and digitized weapons. These interests have intensified the current arms race for the production of efficient defensive weapons by these powerful western countries against the authentic principles of global disarmament, non-proliferation of weapons of mass destruction and peaceful co-existence of member-countries within the framework of the United Nations.

\section{Climate Change and Global Security}

The focus of assessment in this part of the study is on the impacts of climate change on economic activities and social characteristics as they affect the global order and security in the contemporary 21 st Century. We start our analysis first on the economic activities as influenced by climate change. The second part examines the social characteristics in the global habitat as constrained by extreme climatic forces in the current age.

\subsection{The Economic Activities and Challenges}

In the Mediterranean areas of the Middle East, some contiguous parts of the tropical Latin America Central, Mexico, and the Humid Tropics of Africa, extreme climatic forces such as high radiation, gusty winds, risen temperatures, inadequate rainfall and drought have greatly impacted agricultural activities to the extent that outputs have drastically reduced to the level of food insecurity where adequate human satisfaction becomes impossible. More so, torrential rains, overflows of rivers across their natural and cultural banks, extreme surface run-off and exacerbated flooding of the fertile plains owing to reckless human blockade of the drains and pervious surfaces affect the sustained production of adequate food and cash crops, livestock produce, vital vegetables and fruits, and essential vegetal resources particularly in the southern rainforest parts of West Africa and East Africa (Tables 1 and 2).

Adequate production of livestock and related dairy products thrive extensively in the East and West African Sudan agro-regions of the world. Favourable climates, suitable environments, efficient management, and adequately nutritious pastures account for these fruitful livestock activities. As observed, these livestock activities are greatly restricted in the undulating Savannas of these countries owing to harsh climates and unsuitable environments which breed and sustain dangerous species of insects and diseases. The local tsetse flies which cause and transmit trypanosomiases are famous in these areas. High radiation, inadequate pastures, heavy rains, mild humidity, sunshine and sporadically cloudless skies have restricted the regular rearing of livestock, public dairy farming and commercial ranching in these vast undulating plains of Africa. These challenges of livestock rearing and dairy production are completely absent in the Prairies of North America, the Pampas of Argentina, the Veldt of South Africa, and the Downs of Australia. Adequate expert management, suitable climates, conducive environments, scientific researches into sustainable livestock production, usage of advanced livestock technology, reliable energy provisions, and cost-effective labour are responsible for these productive livestock activities which currently override the malevolent impacts of climate change on the agro-sectors of these regions of the world.

Table 1. Extreme Climatic Forces Operational in Tropical Africa and the Latin South America

\begin{tabular}{|c|l|l|}
\hline S/N & Locations & \multicolumn{1}{c|}{ Operational Extreme Climatic Forces } \\
\hline 1 & Africa & $\begin{array}{l}\text { High radiation, high annual temps, high humidity, torrential rains, heavy storms, fluvial, } \\
\text { pluvial and flash flooding, hill-slope flooding, rock-falls, landslides, mudslides, } \\
\text { mudflows, gusty winds, cold and hot winds, sandstorms, heat waves, drought, } \\
\text { desertification, desert denudation, increased sunshine, atmospheric turbulences, vast } \\
\text { cloud covers, sporadic hail falls, agro-pests and insects invasion of settlements and } \\
\text { farmlands, etc. }\end{array}$ \\
\hline 2 & $\begin{array}{l}\text { Latin South } \\
\text { America }\end{array}$ & $\begin{array}{l}\text { High insolation, mean annual temps, high humidity, torrential rainfall, slope and surface } \\
\text { flooding, fluvial flooding, rock-falls, landslides, mudflows, gusty harsh winds, lightning, } \\
\text { thunderstorms, air turbulences, dry whirlwinds, mountain and coastal erosions, hill slope } \\
\text { weathering, ocean surges inlands, droughts, desert encroachment, desert erosion, } \\
\text { sandstorms, etc. }\end{array}$ \\
\hline
\end{tabular}

Source: Field Studies, 2019

The impacts of these occurrences are felt in three phases. In the first phase, adequate food, cash crops and livestock produce become scarce for global community consumption. This is food insecurity. It results to starvation, malnutrition, diseases outbreak, migration of people, and loss of vibrant youths for sustained 
development in these parts of the world. The second phase experiences huge denudation of the fertile plains, submersion of infrastructures, and depletion of vital vegetal resources for diverse uses. The last phase requests the international cooperation, assistance, and aid to resolve these vast environmental and human challenges as they practically defy the normal sovereign interventions. This is where climate change mandatorily engages the international order and security attention for realistic ameliorations in the current 21 st Century.

The failure of agro-activities spurred by severe denudation of the soils, loss of occupations, incomes, and means of sustenance result to migration of the rural farmers, youths, and their trade partners to new urban areas and across foreign borders in search for other viable options for survival. In the new urban areas and foreign lands settled, the anticipated jobs are adequately not accessible to these migrants owing to strict legal principles, education, and citizenship requirements. Having exhausted their means of search for survival in these areas, the migrants would resolve to illicit tactics of diverse crimes to survive. Pickpockets, burglary, drugs trafficking, fraud, abduction of people, armed robbery and terrorism which produce urgent benefits in huge sums of money become the absolute means for survival. These activities attract the security attention of the concerned states and the global community to tame and eradicate.

The malevolent impacts of climate change are directly identifiable in the diverse industrial activities found in the developing humid tropics of the world. The periods of exploration, exploitation and refinement of industrial raw materials in the ambient environment should not be scheduled within the seasons of heavy rainfall, thunderstorms and enervative sandstorms because these extreme climatic forces can destroy vital industrial machinery, spare parts and reserved raw materials. When these options are neglected by the tropical industrialists, the consequences are manifested in periodic distortion, disruption and outright halt of industrial activities. While industrial outputs are reduced significantly in these tropical latitudes, most of the installed industrial machinery would be liable to the severe weathering actions of climate which result to extreme friction and malfunction on the long run. The operations of tropical hurricanes, harsh blizzards and extreme storms have destroyed some industrial machinery installed in some temperate countries of the world. These extreme climate forces have also devastated the built-up facilities, houses and other important structures within the industrial regions in these parts of the world (Tables $1 \& 2$ ).

Table 2. Prevailing Extreme Climatic Forces in the Middle East and Asia

\begin{tabular}{|c|l|l|}
\hline S/N & Locations & \multicolumn{1}{c|}{ Operational Extreme Climatic Forces } \\
\hline 1 & Middle East & $\begin{array}{l}\text { High insolation, high temps }\left(28^{0} \mathrm{C}-48^{0} \mathrm{C}\right) \text {, dry dusty winds, gusty harsh winds, } \\
\text { sandstorms, droughts, desertification, wind erosion, heat waves, cold winds, snow-ice } \\
\text { falls, hailstorms, heavy rains, fluvial floods, flash floods, heat-induced earthquakes, earth } \\
\text { tremors, mountain flooding, slope flooding, extreme cold. }\end{array}$ \\
\hline 2 & Asia & $\begin{array}{l}\text { High insolation, high temps, high humidity, heat waves, cyclonic rains, fluvial floods, } \\
\text { pluvial run-off, landslides, mudslides, mudflows, flash floods, typhoons, blizzards, heat- } \\
\text { induced ocean tsunami and earthquakes, earth tremors, high atmospheric aerosols, cold } \\
\text { winds, icefalls, hailstorms, snow thawing, collapse of ice folds, increased ocean-sea } \\
\text { waters, ocean surges inlands, coastal erosion, glacial falls, glacial erosion, dark cloud } \\
\text { covers, gusty harsh winds, lightning, etc. }\end{array}$ \\
\hline
\end{tabular}

Source: Field Studies, 2019

The brain drift overseas and intermittent power supplies to industries have had adverse impacts on the industrial production activities in the developing tropical countries of Africa and South America. In fact, current research activities on the amelioration of industrial production in these tropical parts of the world are sporadically procrastinated thus leading to poor industrial results and delayed payments of experts and related workers' salaries and allowances. Shut down of industrial activities and flight of experts and workers are the decisive consequences. The diverse markets which trade on locally manufactured goods have partly withdrawn their tentacles, leading to importation of foreign goods for sale at home. This situation obstructs the authentic initiatives of most developing countries to advance significant measures to improve these diverse industrial challenges.

In the temperate latitudes of the world, extreme climate-induced walls of wild fires have occurred. In the heavily forested areas of California, USA, and parts of Australia, recurring wild fire incidents have been observed. These forest fires have devastated countless homes, small-scale industries, agro-firms, private ranches, domestic gardens, and rainfall stations. The closest surroundings and the lamina troposphere were directly polluted by the ascent particulates from the forest fires. The stench breezes produced by the fires made the residents incur catarrh, cough, respiration, and sight ailments in these Hemispheres. Although urgent rehabilitations were carried out by the authorities, the deaths of residents, and the psychological and clinical impacts of the wild fires on the residents remain indelible, till date.

A healthy atmosphere serves as a viably authentic shield to all the living species in the Planet Earth. Its ozone gas, oxygen, moisture, rainfall, and cloud cover act as the major outputs in this regard. It provides adequate rainfall, sunlight, fresh breezes, suitable energy, relative humidity and protective soft clouds for man's 
utilization. In fact, the atmosphere serves as a truly vital stable channel for the smooth movement of airplanes, helicopters, jets, and balloons across the different parts of the world. It enables spacecrafts and all the research, socio-economic, political, and military satellites to gain adequate access to the outer space for precise installation. The exact imageries sent to the earth's processing stations from these satellites are analyzed, the reports are produced, and decisive applications in the suitable sectors are carried out. These functions have made the world a relatively safe, secure, united, comfortable, interdependent, and socio-economically prosperous habitat for the people to live.

In the global habitat today, the adverse impacts of climate change have caused complete reversal of these socio-economic, political, and military benefits facilitated by the smooth and secure transportation in the earth's atmosphere. Recurring turbulences, invisible clouds, unstable jet streams, scattered particulates, blurred skies, dry air masses, accelerated temperatures, and depleted ozone mass exist as the lucid physical characteristics of the global atmosphere. These polluted features continually constitute physical restrictions to daily flights in terms of smooth take-off of airplanes and safe landing at the airports and stable sail in the atmosphere. The poor traits of the atmosphere coupled with torrential rains and hurricanes have resulted to limited air disasters observed in the world in the recent periods. Although experts have argued in favour of mechanical malfunctions and outright engine failures as accountable for these atmospheric disasters, recent assessments of some airplane crash-sites using satellite imageries lucidly indicate that these air mishaps are caused by violent climatic operations and reckless human pollution of the urban atmosphere which lead to mechanical malfunction and engine failure (Ayoade, 2004; John, 2012; Okhakhu, 2016; 2019).

\subsection{The Social Characteristics and Challenges}

The significant social characteristics assessed in the study are comfortable housing, durable roads, secure railways, harbours, and airports which are found in the different countries of the world. The others are suitable offices, viable healthcare and recreational facilities, protected shelters for the new urban settlers, healthy workplaces for productive activities, functional banking facilities, and standard malls. The concern of both the rural and urban residents in this regard is to be timely and regularly accessible to these viable social facilities in a suitable climate immune from discriminatory restrictions imposed by the authorities. More so, there is mandatory need to ensure that these vital social facilities are sustained for permanent utilization. In this study, we regard this practice as 'adequate infrastructure maintenance for healthy human satisfaction.'

The preponderance of extreme climatic forces has reversed this laudable rural-urban infrastructure maintenance, renewal, and sustainability in the global environment in recent time. In fact, heavy rainfall of high frequency and intensity and violent hurricanes spurred by risen temperatures have caused destructive environmental flash flooding across Africa, America, Asia, Australia, Europe, Middle East, and the Caribbean Islands. These significant social facilities have been tremendously impacted to the extent that some have been damaged while a few others are completely annihilated by the violent hurricanes.

Similarly, the heat waves generated by the modified solar energy owing to usage of incompatible construction materials across the global surfaces are causing immense discomfort in the offices, school premises, worship centres, trading malls, at homes, healthcare facilities, banking halls, and in the densely populated towns and cities of the world. Harsh weather conditions are currently being experienced across the global habitat. There are also vast incidents of wild forest fires roughly ignited by thunder claps, lightning and excess radiation which have devastated countless settlements, research centres and equipment, offices, valuable resources, and killed many urban residents in Africa, Australia, Europe, America, and the Middle East. Currently, most of the settlements built in the continental and marginal locations of the world are being invaded by frequent sandstorms, enervating gusty winds, debilitating droughts, extreme cold winds, icefalls, and deadly migratory desert phenomena (Table 3).

The devastation of some vital coastal settlements by ocean-sea surges inlands induced by violent hurricanes and tropical storms and immense flash flooding of the continental habitats caused by heavy rains and rivers overflowing their natural and artificial banks have given rise to displacement of the residents which spurs diverse migrations within and across the foreign borders of different countries. Agenebode, Fugar, Idah, Bayelsa, Warri, and Lagos in Nigeria; Sulawesi in Indonesia; Texas, Florida, and New Orleans in the USA; Lisbon, Portugal; and Haiti and Kingston in the Caribbean Islands are important coastal settlements impacted in this regard. However, the inadequacy of fundamentally required satisfactory socio-economic and political provisions for these migrant settlers in their new settlements within the states and foreign destinations results to emergence of serious security issues. These issues include, inter-alia, resident and migrant protests, migrants persistent requests for satisfactory sustenance, pollution of the receptive habitats, rebellions against the resident authorities, petty crimes, and partial break down of law and order. 
Table 3. Extreme Climatic Forces Predominant in Australia, Europe and North America

\begin{tabular}{|l|l|l|}
\hline S/N & Locations & \multicolumn{1}{c|}{ Operational Extreme Climatic Forces } \\
\hline 1 & Australia & $\begin{array}{l}\text { Moderate-high temps, high humidity, heavy rainfall, thunderstorms, flash floods, snow } \\
\text { thawing, ice folds collapse, increased ocean-sea waters, coastal flooding, fluvial erosion, } \\
\text { high cloud covers, hail falls, hailstorms, harsh cold winds, gusty cool winds, desert erosion, } \\
\text { wild forest fires, atmospheric turbulences, lightning. }\end{array}$ \\
\hline 2 & Europe & $\begin{array}{l}\text { Mild radiation, high temps, high humidity, warm winds, torrential rainfall, flash floods, } \\
\text { fluvial and pluvial floods, thawing of permafrost, snow-ice falls, ice folds collapse, } \\
\text { blizzards, risen ocean-sea waters, coastal floods, sea surges inlands, glacial erosion, harsh } \\
\text { cold winds, dry dusty winds, gusty winds, wild forest fires, seasonal insects invasion of } \\
\text { settlements and farmlands, atmospheric aerosols. }\end{array}$ \\
\hline 3 & $\begin{array}{l}\text { North } \\
\text { America }\end{array}$ & $\begin{array}{l}\text { Temperate rains, tropical storms, hurricanes, tornadoes, heavy rainfall, blizzards, flash } \\
\text { floods, ocean surges inlands, icefalls, cold icy winds, gusty harsh winds, dry winds, wild } \\
\text { forest fires, thunderstorms, lightning, dark clouds, heat waves, air turbulences, fluvial- } \\
\text { pluvial erosion, inland flooding, heat-induced earthquakes, mountain flooding, landslides, } \\
\text { mudflows, surface denudations, etc. }\end{array}$ \\
\hline
\end{tabular}

Source: Field Studies, 2019

As observed, significant recreation sites with therapeutic facilities have been damaged by heavy rainstorms, hurricanes and blizzards across the world. Important ancient and medieval settlements, research sites, and unique ecosystems of natural biodiversity regarded as world's vital heritage resources have been partly damaged by thunderstorms, flash floods, gusty winds, and wild fires. Particularly in the developing humid topics of the world, the energy distribution facilities, dams, boreholes, water reservoirs, and agro-industrial establishments are dislodged and shattered by the raging torrential rains and ravaging excess run-off on the rural-urban surfaces. Consequently, the routine energy and drinking water provisions to different rural-urban settlements are cut-off, thus resulting to disruptions of artisan and formal activities, outbursts of heat crises in the living homes and workplaces, and consumption of impure drinking waters fetched from the local streams and rivers which causes cholera, dysentery, and diarrhea among the children and the rural-urban residents.

The occurrence of poor weather such as heavy rainfall results to delay, postponement, or outright cancellation of organized sport events in some major cities of the world. Turbulent atmospheric conditions such as the occurrences of heavy rainfall, hailstorms, sandstorms, whirlwinds, and invasion of deadly insects have caused the disruptions of some scheduled important political rallies, religious crusades, sport events, recreation activities, social enlightenments, and economic enhancement programs across the world. In fact, raging floods have, in recent periods, submerged many houses, offices, market grounds, agro-industrial complexes, roads, coastal harbours, airports, train stations, farm sites, school premises, praying grounds, research institutes, mining and quarrying zones, and sand recovery sites in some parts of the world. The recent cases of Sulawesi and Sumatra in Indonesia, India, Japan, Nigeria, Portugal, Russia, and Texas in the USA are realities to place in modern scientific studies.

The excess radiation of living homes and their surroundings in most cities have led to emergence of human heat cramps, body rashes, profuse sweating, dehydration and other fatal illnesses in recent time. The present heat wave experiences in Japan, China, America, Iran, Iraq, Pakistan, Syria, Jordan, Israel, Egypt, Libya, Sudan, Niger, Mali, Senegal, Kenya, Guinea, and Eritrea are empirical illustrations to place on records. More so, some of the flooded surfaces in the humid tropics of the world have become the suitable breeding habitats for mosquitoes, and specifically the dangerous female anopheles mosquitoes which cause and disseminate the life killing malaria; needless to mention the disgusting noise pollutions of these tropical insects in our houses during the night hours of scientific scrutiny of literature, silent meditations for healthy mind and body, relaxation, and normal night sleep.

The diverse extreme climatic forces generated by climate change which are operational in the humid tropics, mid-latitudes, temperate, and the polar regions of the world are shown in Tables 1, 2 and 3 of the study. In Africa and the Latin South America, similar extreme climatic forces prevail and these include high radiation, high mean temperatures, heavy rains, thunderstorms, gusty winds, fluvial and pluvial floods, flash floods, air turbulences, landslides, mudflows, and dark cloud covers. Cyclonic rains, typhoons, flash floods, coastal erosion, high radiation, risen temperatures, heat waves, sandstorms, droughts and desertification, inter-alia, are prevalent in Asia and the Middle East. Australia, Europe, and North America are continually receptive of high humidity, torrential rains, gusty winds, fluvial floods, flash floods, hurricanes, tornadoes, blizzards, ice folds collapse, risen ocean-sea waters, coastal flooding and erosion, air instability, wild forest fires, heat waves, and dark cloud covers. These operational extreme climatic forces, as observed in the field studies, are the predominant causes of the current environmental, socio-economic, and human challenges in Africa, Asia, Australia, Europe, Latin South America, North America, and the Middle East. 


\section{Research Findings}

Founded on authentic assessments of climate change and global security in the current 21 st Century from the geo-political perspectives, the following findings were made.

The study observed the prevalence of high radiation, increased temperatures, heavy rainfall, flash floods, gusty winds, sandstorms, droughts and desert conditions which greatly impacted agro-activities to the level of food insecurity in the Mediterranean North of the Middle East, Latin America Central, and the Humid Tropics of Africa. These events resulted to loss of gainful jobs and incomes, advent of starvation, malnutrition and diseases, and chaotic global migration of people.

The inadequacy of the basic human necessities for sustenance caused by climate change, decrepit governance, poor distribution of national resources, decayed rural-urban infrastructures, deepening youth unemployment, ethnic cleansing, terrorist attacks in major cities, and incessant decimations of innocent citizens have led to reckless power shifts and protracted deadly wars in some African countries.

It observed that climate change had disrupted not only the periods of exploration, exploitation and refinement of vital industrial raw materials but it also damaged parts of the installed industrial machinery and affiliated facilities which led to reduced industrial outputs, shut down of operations, and flight of human resources in some parts of Africa, the Middle East, Asia and Latin America to Australia, Europe and North America.

The study observed the occurrences of extreme climate-induced walls of forest fires which burnt down countless living houses, small-scale industries, agro-establishments, private-owned ranches, domestic gardens, and polluted the immediate environments during the summers in California, USA, and some parts of Australia.

It revealed that extreme climatic operations as torrential rains, flash floods, landslides, mudslides, violent hurricanes, and wild forest fires have destroyed important socio-economic facilities and killed many rural-urban residents in the Gambia, Sierra-Leone, Kenya, Zimbabwe, Sudan, Mozambique, Bangladesh, India, Burma, Honduras, Indonesia, Japan, and the USA.

The study noted the existence of a vastly stable and healthy atmosphere which served as a shield to both physical and human communities occupying the underlying environments. Its uses as safe conveyance of experts, education equipment, skilled services, different manufactures and classified military weapons by circulating diverse airplanes makes the world a relatively secure, united, comfortable, interdependent, and socioeconomically prosperous habitat to live by its peoples.

The study observed the preponderance of atmospheric turbulences, invisible clouds, dynamic jet streams, scattered particulates, dry air masses, accelerated temperatures and depleted ozone mass as the visible physical features of the current global atmosphere. These polluted features currently pose immense restrictions to the smooth flights of airplanes which contribute to mechanical malfunctions and engine failures resulting to airplane crashes across the world in the recent period.

The study observed the inability of the migrant youths to secure sustainable means of survival in the foreign lands as the major cause of coercion into illicit activities which spanned stealing, fraud, ritual magic, impersonation, drugs trafficking, prostitution, vandalism, burglary, armed robbery, and deadly attacks in the restaurants, recreation sites, schools, markets, bank halls, worship centres, and international highways.

The study noted the prevalence of harsh weather conditions particularly the radiation of hot winds and excess heat waves which currently cause serious human discomfort in the offices, living homes, worship centres, health institutions, recreation sites, schools, and densely peopled towns and cities of the world.

It observed the partial submersion of some important coastal settlements in the temperate and polar locations of the world owing to ravaging hurricanes and mild thawing of permafrost spurred by risen mean temperatures and devastation of significant therapeutic recreation sites by rainstorms and wild forest fires.

Finally, the study observed the disruption of energy generating and water supply facilities to urban residents by hurricanes, devastation of ancient and medieval settlements by wild forest fires, alteration of unique ecosystems of natural biodiversity by ravaging flash floods, and rescheduling of planned political rallies, religious crusades, sports activities, social enlightenments, and economic enhancement programs owing to occurrences of torrential rains across the different climatic regions of the world.

\section{Policy Recommendations and Implications}

The study shows the existence of food insecurity in the Middle East, Latin American Central, and the Humid Tropics of Africa owing to operational extreme climatic forces and poor governance. As solutions, we suggest the urgent activation and practice of all the productive agro-reforms to be prudently managed by skilled agroexperts across these climatic latitudes of the world. In this regard, authentic government piloted by responsible, expertly trained, and trustworthy leaders should be empowered through fair, credible, and virtually flawless elections to administer these regions. The positive impacts of these regimes would trickle down to resuscitate these agro-sectors for tremendous outputs production. Based on reduced food prices in the markets, the residents of these regions would be able to afford their normal daily food requirements for healthy sustenance. All restless 
agitations for local and foreign migrations would be arrested holistically. This measure would prevent hatch of crimes and install stable socio-economic and political orders in the global system. Of course, the Ministries of Agriculture and Natural Resources of these countries should embark on balanced distribution of food, livestock produce and other vital resources at affordable prices to reduce the exacerbated poverty levels of their citizens. Regular payment of salaries to the workers and socio-economic provisions to the jobless people would stabilize the chaotic economic situations.

It is necessary to resuscitate the rural-urban renewal process in these extreme climate impacted countries of the world. Also, there should be effective rehabilitation of worn-out surface infrastructures through urgent deployment of expert civil engineers, architects and builders, and the requisite resources. Commensurate agricultural, mining, construction, manufacturing, refining, pharmaceutical, commercial, and tertiary industries should be established to absorb the explosive crowds of jobless youths in these countries. Having achieved these levels of development, there would be stable political orders, territorial security, and socio-economic stability in these countries. The recurring terrorist attacks and assorted crimes in the world's cities would be greatly minimized. Consequently, the reckless agitations for power shifts which result to deadly civil-military wars in Africa, Asia, Latin America, and the Middle East would be largely tamed from the bud, if not resolved permanently at the round table talks among the aggressive parties.

Adequately authentic global climate data-banks should be developed by all the member-countries which constitute the current United Nations. These climate data-banks would have to be regularly updated, pooled, documented, made available, and distributed among the world's countries by using the most recent advanced weather satellites for environmental and human applications. Fundamentally, the infusion of authentic global climate data into routine economic activities would help make effective plans for beneficial exploration, exploitation, and refinement of vital crude oil resources in modern industries immune from extreme climateinduced risks, dangers and devastations. To this end, the unabated challenges which relate to visible scarcity of industrial raw materials, devastations of installed machinery, shut down of operations, accumulated unpaid workers' salaries and allowances, flight of experts, and redundancy of local work forces would be directly put at bay. This situation implies renewed resuscitation of previous mining and associated industries which could absorb the diverse crowds of old and new workers into their folds. Consequently, the chaotic global migrations of healthy bodied jobless youths would be partly restrained. There would be crime reduction and creation of stable and sustainable order of security in the global habitat.

Across the global habitat today, significant settlements, small-scale industries, public plantations, privateowned ranches, domestic gardens, and related government industries and schools should not be established close to thickly forested areas which are always susceptible to diverse fire events during the dry summer periods. In fact, selective raking, packing and removal of shed forest leaves, dead trunks and woods should be promptly carried out by using suitable forest sanitary tractors. This forest sanitation should be adequately funded and implemented by the authorities and specialists of the impacted countries. To this end, the forest fires and impacts on the local, state, regional, and national resources would be reduced to virtually zero-level. Of course, during the spring, there would be a renewed resurgence of the usual forest resources covering valuable animals, plants, birds, insects, soils, ropes, herbs, reptiles, and water.

As long as high radiation and risen temperatures prevail, there would always be heavy rains, flash floods, landslides, mudslides, rock-falls, violent hurricanes and wild forest fires across the world. However, there are effective measures to control and tame these devastative climatic operations. First, robustly resistant structures should be built on the environment. With regard to houses, offices, roads and socio-economic facilities, reinforced standard materials should be used for their construction in the sites prone to these extreme climatic forces. Given adequate funds, reliable technology, and deployment of specialists in climatology, building, architecture, quantity, civil and structural engineering, these diverse facilities could be built as if they are permanent bunkers. Second, there should be permanent avoidance of unsafe areas liable to hurricanes, blizzards, landslides, mudslides, and wild forest fires with regard to physical constructions.

Finally, functionally permanent surface and subterranean run-off discharge channels and trenches should be built to absorb, reduce, and terminate seasonal heavy rain and flash flood events across the different global climatic latitudes. When these measures are realized, the devastations caused periodically by flooding and flash floods would be largely tamed.

Currently, the world must rely on, incorporate, and utilize the exact meteorological data provided by the diverse international weather satellites in her routine environmental and human activities. The weather data should be utilized to detect the periods of occurrences of these extreme weather forces. Based on the findings, the people could avoid these risky forces by keeping safe indoors in secure bunker-like houses and related facilities specially built to surmount these dangerous events.

In the transport sector, users of airplanes, ships, trains and automobiles should monitor the advent of these dangerous weather events and strive to avoid their physical impacts. The adherence to and implementation of these measures would result to pragmatic reduction and prevention of virtually all types of transport mishaps in 
the world's environments.

At the start of physical infrastructure constructions, some natural vegetation and marshy landscapes should be preserved on the sites. Some artificial green zones should be created also. Both the preserved and artificially created vegetation would radiate natural refreshing breezes on the surroundings timelessly while the marshy landscapes would absorb the atmospheric radiation thereby reducing the heat impacts on the built physical facilities and overall environment. These measures should be applied in the towns and cities of both developing and the developed countries of the world in order to tame the increasing heat stresses on the human occupants, live animals, plants and birds.

To ensure practical interventions against the devastations of coastal cities by hurricanes, blizzards, and ocean-sea surges inlands, we suggest the use of solid iron railings and reinforced concrete materials to construct suitably fortified moderate walls to ward-off their seasonal recurrences. In extreme situations, urgent evacuations of strategic resources and the residents of liable cities are necessary. More so, the energy and water supply cables and pipes which must be of the best quality should be installed beneath the crust to avoid direct destructive contacts with the extreme climatic forces. Wild forest fires which should be lucidly monitored using standard satellites must be nipped from the bud. Where the fires sprout, the flames should be timely quenched using standard fire-fighting equipment by the experts. For huge successes to be achieved with regard to political rallies, sport events, social recreations, and economic promotions, reliable global climate data must be incorporated in the programs and utilized for the initial planning phases.

More so, the reckless release of dangerous greenhouse gases into the earth's atmosphere by the agroindustrialized countries should terminate and give way to utilization of environmental friendly energies which are relatively clean, renewable, affordable, and efficient. The best energies in this aspect are solar, geothermal, water, wind, tidal and ethanol. In this regard, proper environmental sanitation is needed at the various sites of crude oil and gas explorations, exploitations and refinements across the world. All mining, quarrying, and mineral refining activities on the global habitat should be properly regulated, monitored, and diligently executed by experts. Also, there should be international ban on the use of chlorofluorocarbons to produce coolants, fire extinguishers, solvents, foaming agents, aerosol propellants, and agro-pesticides. New ethics and functional technologies should be devised to help control and stabilize greenhouse gas emissions into the atmosphere. The reliance on carbon sinks, carbon capture, and carbon storage in safe locations and emissions trading, and adherence to the concept of improved energy efficiency in the homes and public places would also help reduce greenhouse gas emissions into the environment.

All the measures enunciated and ratified in the past international conferences on climate change mitigation and prevention and the current global decisions made at the just concluded Poland Conference held in Katowice should be adhered to and boldly executed. In addition, the current world's socio-economic and political challenges particularly the deadly wars and starvations across Africa, the Middle East, and Asia should be resolved at the Round Table Conferences in the United Nations by the warring parties. Above all, national and acceptable global interests which sustain the inhabitants of the Planet Earth should be pursued against the hegemonic gains of some groups which breed discord, hatred, pollution of the environment, civil protests, political dichotomies, terrorism, and devastative wars.

\section{Conclusion}

This study has examined climate change and global security from the geopolitical perspectives in the current 21 st Century. Using the specialist realist approach, it observed that climate change was induced by natural processes and human activities which defied standard environmental principles of routine sanitation, even maintenance, prohibition, mitigation, regeneration, rehabilitation, and permanent sustenance. Across the world, as the study observed, climate change has devastated the natural environments, settlements, human economic activities, and the built social facilities. These events resulted to food insecurity, joblessness, loss of wealth, political instability, migration overseas, hatch of diverse crimes, reinforced terrorism, and deadly civil-military wars which disrupted the global orders of stability, security, and peaceful human co-existence. Based on this premise, the study suggests efficacious measures to restore global security in climate change mitigation, prevention, and eradication, sound environmental maintenance, regeneration and sustenance, adequate food, job and social benefit provisions, surface vegetal development, deployment of experts' services in agriculture, industrialization, housing, and transportation sectors, military intelligence and overall combat, recreation, human evacuation, and fire-prevention based on adequate resources provision by the public-private authorities, sovereign governments, and international agencies.

\section{References}

Ayoade, J.O. (2004). Introduction to Climatology for the Tropics. Ibadan: Spectrum Books Limited. 182-194.

Beres, L.R. (1979). Terrorism and Global Security. The Nuclear Threat. Boulder, Colorado: Westview Press Inc. 4-9. 
Brown, J. D. (2004). 'Knowledge, Uncertainty, and Physical Geography: Towards the Development of Methodologies for Questioning Beliefs.' Transaction of the Institute of Physical Geographers. 29, 367- 381.

Collins, B. (2010). Collins Senior Secondary Atlas for Nigeria. London: Harper Collins Publishers. 16-19.

John, G. (2012). 'Climate Change: An Unprecedented Environmental Challenge.' In Joseph, H. (Ed.) An Introduction to Physical Geography and the Environment. England: Pearson Education Limited. 712- 716.

Joseph, H. (2012). 'Approaching Physical Geography.' In Joseph, H. (Ed.) An Introduction to Physical Geography and the Environment. England: Pearson Education Limited. 7-15.

Lane, S. N. (2001). 'Constructive Comments on D. Massey's Space-time, Science and the Relationship between Physical and Human Geography.' Transactions of the Institute of British Geographers. Vol. 26, 243-250.

Makinda, S.M. (1998). 'Sovereignty and Global Security, Security Dialogue.' Sage Publications. Vol. 29 (3). 281-292.

Mc Clatchey, J. (2012). 'Global Climate and Weather.' In Joseph, H. (Ed.) An Introduction to Physical Geography and the Environment. England: Pearson Education Limited. 140-156.

Mc Sweeney, B. (2003). Security, Identity and Interests: A Sociology of International Relations. Cambridge: Cambridge University Press. 4-14.

Okhakhu, P.A. (2015). 'Climate Change: An Unprecedented Environmental Challenge.' Journal of Environment and Earth Science. Vol. 5, No. 4. 9-19.

Okhakhu, P.A. (2016). 'Rural Development and Environmental Protection in Nigeria.' Developing Country Studies. Vol. 6, No.1, 131-138.

Okhakhu, P.A. (2019). Fundamentals of Tropical Climatology. Ekpoma: Ambrose Alli University Press. 124142.

Okhakhu, P.A. (2019). Research Methods in Climatology. Ekpoma: Ambrose Alli University Publishing House. 65-84. 